\title{
Bioconversion of biphenyl to a polyhydroxyalkanoate copolymer by Alcaligenes denitrificans A41
}

\author{
Taito Yajima ${ }^{1}$, Mizuki Nagatomo ${ }^{1}$, Aiko Wakabayashi' ${ }^{1}$ Michio Sato ${ }^{1}$, Seiichi Taguchi ${ }^{2}$ and Michihisa Maeda ${ }^{*}$ (0)
}

\begin{abstract}
A polyhydroxyalkanoate (PHA) copolymer, poly(3-hydroxybutyrate-co-3-hydroxyvalerate) [P(3HB-co-3HV)], was biosynthesized from biphenyl as the sole carbon source using Alcaligenes (currently Achromobacter) denitrificans A41. This strain is capable of degrading polychlorinated biphenyls (PCBs) and biphenyl. This proof-of-concept of the conversion of aromatic chemicals such as the environmental pollutant PCBs/biphenyl to eco-friendly products such as biodegradable polyester PHA was inspired by the uncovering of two genes encoding PHA synthases in the A. denitrificans A41 genome. When the carbon/nitrogen (C/N) ratio was set at 21, the cellular P(3HB-co-3HV) content in strain A41 reached its highest value of $10.1 \%$ of the cell dry weight (CDW). A two-step cultivation protocol improved the accumulation of $\mathrm{P}(3 \mathrm{HB}-\mathrm{CO}-3 \mathrm{HV})$ by up to $26.2 \%$ of the $\mathrm{CDW}$, consisting of $13.0 \mathrm{~mol} \% 3 \mathrm{HV}$ when grown on minimum salt medium without nitrogen sources. The highest cellular content of $\mathrm{P}(3 \mathrm{HB}-\mathrm{CO}-3 \mathrm{HV})(47.6 \%$ of the CDW) was obtained through the two-step cultivation of strain A41 on biphenyl as the sole carbon source. The purified copolymer had ultra-high molecular weight (weight-average molecular weight of $3.5 \times 10^{6}$ ), as revealed through gel-permeation chromatography. Based on the genomic information related to both polymer synthesis and biphenyl degradation, we finally proposed a metabolic pathway for the production of $\mathrm{P}(3 \mathrm{HB}-\mathrm{CO}-3 \mathrm{HV})$ associated with the degradation of biphenyl by strain A41.
\end{abstract}

Keywords: Bioremediation, Metabolic pathway, Polyester, Synthase, Two-step cultivation

\section{Introduction}

There are currently two biotechnological approaches for managing environmental problems: the bioremediation of target pollutants and the synthesis of eco-friendly products. As representative players of bioremediation approaches, Achromobacter and Alcaligenes spp. contain chromosomally encoded genes for the catabolism of phenol and catechol via the meta-cleavage pathway (Hinteregger and Streichsbier 2001; Collard et al. 1994). Some species have also acquired additional genes that extend their metabolic capabilities to include the degradation of

\footnotetext{
*Correspondence: mmaeda@meiji.ac.jp

1 Microbial Genetics Laboratory, Department of Agricultural Chemistry, School of Agriculture, Meiji University, 1-1-1 Higashimita, Tama-ku, Kawsaki, Kanagawa 214-8571, Japan

Full list of author information is available at the end of the article
}

polychlorinated biphenyls (PCBs) and other halogenated aromatic compounds (Springael et al. 1993; Springael et al. 1994). The degradation of these cytotoxic molecules typically proceeds through a series of dehalogenations and aromatic ring oxidations that convert the molecule into catechol, after which it enters into the meta-cleavage pathway and undergoes further metabolic conversion to acetate and pyruvate (Hughes and Bayly 1983).

A PCBs degrader, Alcaligenes denitrificans strain A41 is a Gram-negative, organic solvent tolerant, alkalitrophic, and denitrifying bacterium (Ohta et al. 1996; Maeda et al. 1998). The taxon of Alcaligenes denitrificans was reclassified as Achromobacter denitrificans (Coenye 2003). In our previous studies (Maeda et al. 1997; Tomizawa et al. 2015), a set of genes responsible for the metabolism of

\section{SpringerOpen}

(c) The Author(s) 2020. This article is licensed under a Creative Commons Attribution 4.0 International License, which permits use, sharing, adaptation, distribution and reproduction in any medium or format, as long as you give appropriate credit to the original author(s) and the source, provide a link to the Creative Commons licence, and indicate if changes were made. The images or other third party material in this article are included in the article's Creative Commons licence, unless indicated otherwise in a credit line to the material. If material is not included in the article's Creative Commons licence and your intended use is not permitted by statutory regulation or exceeds the permitted use, you will need to obtain permission directly from the copyright holder. To view a copy of this licence, visit http://creativeco mmons.org/licenses/by/4.0/. 
PCBs and biphenyl was found in the genome of Alcaligenes denitrificans strain A41.

While sequencing the whole genome of strain A41, we also found genes related to the synthesis of biodegradable polymers known as polyhydroxyalkanoates (PHAs) at different loci. This finding is in accordance with the fact that strain A41 is related to Alcaligenes eutrophus (currently Ralstonia eutropha), a known PHA producer (Schlegel et al. 1961; Raberg et al. 2018). Considering these findings, we aimed to establish a promising platform based on strain A41 for the conversion of PCBs and biphenyl to PHAs through a one-pot fermentation process by combining both degradation and synthetic pathways.

In the present study, this proof-of-concept (Fig. 1) conversion of xenobiotic compounds into value-added products such as PHAs was studied using nitrogen limitation conditions, as routinely performed for PHA production with $R$. eutropha. As a result, we achieved the biosynthesis of a PHA copolymer, poly(3-hydroxybutyarate-co3-hydroxyvalerate) $[\mathrm{P}(3 \mathrm{HB}-c o-3 \mathrm{HV})]$ from biphenyl as the sole carbon source. The copolymer production was further improved by conducting a two-step fermentation with growth and polymer production phases. Moreover, we evaluated the molecular weight and monomeric composition of the biosynthesized polymer. Finally, we proposed a pathway for $\mathrm{P}(3 \mathrm{HB}-\mathrm{co}-3 \mathrm{HV})$ production from biphenyl based on our experimental results and on the available genome sequence information.

\section{Materials and methods}

\section{Bacterial strains and media}

Alcaligenes denitrificans A41 (deposited in WDCM567 as JCM9787) was cultured in Luria-Bertani (LB) medium (Sambrook et al. 2001) or $\mathrm{C}$ medium, which contained (per liter) $5 \mathrm{~g}$ of $\left(\mathrm{NH}_{4}\right)_{2} \mathrm{SO}_{4}, 2.93 \mathrm{~g}$ of $\mathrm{KH}_{2} \mathrm{PO}_{4}, 5.87 \mathrm{~g}$ of $\mathrm{K}_{2} \mathrm{HPO}_{4}, 0.3 \mathrm{~g}$ of $\mathrm{MgSO}_{4} \cdot 7 \mathrm{H}_{2} \mathrm{O}, 2 \mathrm{~g}$ of $\mathrm{NaCl}, 0.03 \mathrm{~g}$ of $\mathrm{CaCl}_{2}, 0.01 \mathrm{~g}$ of $\mathrm{FeSO}_{4} \cdot \mathrm{H}_{2} \mathrm{O}, 0.6 \mathrm{mg}$ of $\mathrm{NiSO}_{4} \cdot 7 \mathrm{H}_{2} \mathrm{O}$, and $2 \mathrm{~mL}$ of a trace element solution; the $\mathrm{pH}$ was adjusted to 7.0 using $\mathrm{NaOH}$. The trace element solution contained

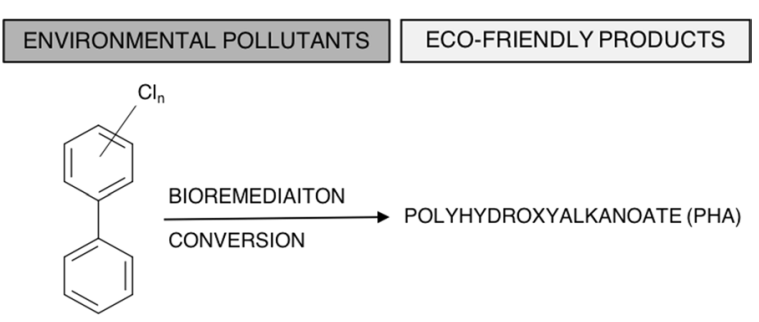

POLYCHLORINATED BIPHENYLS/BIPHENYL

Fig. 1 A conceptual scheme of the conversion of environmental pollutants, such as polychlorinated biphenyls/biphenyl, to eco-friendly products, such as polyhydroxyalkanoates (PHAs) (per liter) $4 \mathrm{mg}$ of $\mathrm{MoO}_{3}, 28 \mathrm{mg}$ of $\mathrm{ZnSO}_{4} \cdot 5 \mathrm{H}_{2} \mathrm{O}, 2 \mathrm{mg}$ of $\mathrm{CuSO}_{4} \cdot 5 \mathrm{H}_{2} \mathrm{O}, 4 \mathrm{mg}$ of $\mathrm{H}_{3} \mathrm{BO}_{3}, 4 \mathrm{mg}$ of $\mathrm{MnSO}_{4} \cdot 5 \mathrm{H}_{2} \mathrm{O}$, and $4 \mathrm{mg}$ of $\mathrm{CoCl}_{2} \cdot 6 \mathrm{H}_{2} \mathrm{O}$. Biphenyl was added to the $\mathrm{C}$ medium at a final concentration of $0.5 \%$ (not dissolved) or $0.3 \%$ as the sole carbon source, and cultures were incubated on a reciprocal shaker in $500-\mathrm{mL}$ flasks containing $100 \mathrm{~mL}$ of the medium at $120 \mathrm{rpm}$ and $30^{\circ} \mathrm{C}$. Antibiotics were adequately used as described previously (Sambrook et al. 2001).

For the one-step cultivation, the concentrations of nitrogen sources were altered to achieve a nutrient-deficiency condition that induced PHA production. For this, we used $\mathrm{C}$ medium containing $0.5 \%$ biphenyl as the sole carbon source and $\left(\mathrm{NH}_{4}\right)_{2} \mathrm{SO}_{4}$ as the nitrogen source at concentrations changed by $1 / 10(\mathrm{~N}-100), 1 / 20(\mathrm{~N}-50)$, $1 / 40(\mathrm{~N}-25)$ and $1 / 100(\mathrm{~N}-10)$ of the original value $(\mathrm{N}-1000, \mathrm{C} / \mathrm{N}$ ratio $=2)$. These altered media had corresponding $\mathrm{C} / \mathrm{N}$ ratios of $21,41,83$, and 166 , respectively.

In the two-step cultivation protocol, the first growth step, which was aimed at gaining cell mass, was performed on LB complex medium until the stationary growth phase was reached, and the second culture used $\mathrm{C}$ medium (without any nitrogen source) containing $0.5 \%$ biphenyl for PHA production. In between the two phases, cells were harvested using centrifugation and resuspended in the second medium.

In an ideal case, cells were grown using $\mathrm{C}$ medium containing $0.3 \%$ biphenyl as the first culture, then harvested after $36 \mathrm{~h}$, and their initial dry cell weight was adjusted to $1.38 \mathrm{~g} / \mathrm{L}$ for resuspension in $\mathrm{C}$ medium without nitrogen sources containing $0.3 \%$ biphenyl. This medium was then used for growth aiming PHA production.

Cells were harvested at several time points (from 6 to $108 \mathrm{~h}$ ) by centrifugation at $4{ }^{\circ} \mathrm{C}$ and were then washed with distilled water and lyophilized.

\section{Polymer analysis using gas chromatography (GC) and gel permeation chromatography (GPC)}

The cellular PHA content and polymer composition were determined by analyzing freeze-dried cells using GC. Approximately $15 \mathrm{mg}$ of dry cells were subjected to methanolysis with a solution consisting of $1.7 \mathrm{~mL}$ methanol, $0.3-\mathrm{mL} 98 \%$ sulfuric acid, and $2.0 \mathrm{~mL}$ chloroform at $100{ }^{\circ} \mathrm{C}$ for $140 \mathrm{~min}$ to convert the constituents to their methyl esters (Braunegg et al. 1978). The addition of $1 \mathrm{~mL}$ water to the reaction mixture induced phase separation. The lower chloroform layer was used for GC analysis on a B353B system (GL Sciences, Eindhoven, The Netherlands) equipped with an InertCap1 capillary column $(30 \mathrm{~m} \times 0.25 \mathrm{~mm})$ and a flame-ionization detector.

The polymers accumulated in cells were extracted using chloroform for $48 \mathrm{~h}$ at room temperature and purified by reprecipitation with methanol. Their molecular mass was 
measured using a GPC 20A GPC system and 10A refractive index detector (Shimadzu, Kyoto, Japan) with Shodex $\mathrm{K}-806 \mathrm{M}$ and K-802 columns. Chloroform was used as the eluent at a flow rate of $0.8 \mathrm{~mL} / \mathrm{min}$, and samples were applied at $1.0 \mathrm{mg} / \mathrm{mL}$. Polystyrene standards with low polydispersity were used in the construction of a calibration curve.

\section{Biphenyl consumption analysis}

Solid-state biphenyl was sterilized using ultraviolet radiation for 5 min on a clean benchtop. Strain A41 was cultured in a test tube with a screw cap containing $10 \mathrm{~mL}$ of $0.5 \%$ biphenyl $(\mathrm{w} / \mathrm{v})$. To evaluate the residual amount of biphenyl in triplicate at nine time points: $12 \mathrm{~h}, 24 \mathrm{~h}$, $36 \mathrm{~h}, 48 \mathrm{~h}, 60 \mathrm{~h}, 72 \mathrm{~h}, 84 \mathrm{~h}, 96 \mathrm{~h}$, and $108 \mathrm{~h}$, the fraction of biphenyl was carried out as follows. To each culture sample, $10 \mathrm{~mL}$ of ethyl acetate (Wako Japan Co. Ltd., Osaka, Japan) was added and mixed well, and samples were then subjected to centrifugation $(3300 \times g$ for $10 \mathrm{~min}$.) using an MX-300 centrifuge (TOMY Co. Ltd., Tokyo, Japan). The supernatants were filtered with a polyvinylidene fluoride (PVDF) filter (13 mm diameter, pore size $0.22 \mu \mathrm{m}$, Merck Millipore, Burlington, USA). Samples were subjected to high-performance liquid chromatography (HPLC) for measuring the consumption of biphenyl as a solid compound during bacterial cultivation. The following setup was used in our experiments: Gilson 305 and 306 pumps (Gilson, Lewis Center, USA); an Ascentis C18 $15 \mathrm{~cm} \times 4.6 \mathrm{~mm}, 5 \mu \mathrm{m}$ column (SUPELCO, Apex Scientific, Kildare, Ireland), detection at $246 \mathrm{~nm}$; and solvent composition consisting of $\mathrm{H}_{2} \mathrm{O}$ and acetonitrile (ratios of 3 and 7), and a flow rate of $1.0 \mathrm{~mL} / \mathrm{min}$. For biphenyl quantification, a benzene calibration curve was used as an internal reference.

\section{Transmission electron microscopy for the observation of polymer accumulation}

Cells were harvested, washed twice in $0.1 \mathrm{M}$ phosphate buffer ( $\mathrm{pH} 7.0)$, and fixed in $2 \%(\mathrm{w} / \mathrm{v})$ glutaraldehyde in the same solution. Subsequently, cells were suspended in $2 \%(\mathrm{w} / \mathrm{v}) \mathrm{OsO}_{4}$ for $1 \mathrm{~h}$, gradually dehydrated in ethanol [50\%, 70\%, 80\%, 90\%, and 99.5\% (v/v); 15 min each], and embedded in Quetol651. Ultrathin sections (thickness $70 \mathrm{~nm}$ ) were cut with a microtome using a Diatome diamond knife. The sections were collected using 400-mesh cupper grids coated with a carbon layer and observed in a Jeol-2010 electron microscope (Jeol Ltd., Akishima, Japan).

\section{Genetic analysis}

The functionality of the phaC gene from A. denitrificans A41 was evaluated using a gene disruption technique. The primers 5'-ATTCTAGACTGGACCCGGAATGCAAC- ${ }^{\prime}$ and 5 -ATGGTACCCATCCCGCCTGTAACGTAAG- ${ }^{\prime}$ were used to amplify the phaC1 (ade) gene from the $A$. denitrificans A41 genome. The resulting amplicon was used as a probe for a subsequent colony hybridization. According to the available genome information for A41, the phaC1B1R locus can be efficiently cloned as a 5997bp KpnI fragment. The bacterial chromosome was, therefore, digested with the KpnI endonuclease (Takara Bio, Shiga, Japan), a gel fragment containing approximately 6-kb DNA was cut out, and the extracted DNA fragments were cloned into the pUC19 vector (Takara Bio, Shiga, Japan). The DNA library obtained here was subjected to colony hybridization (Grunstein and Wallis 1979). Positive colonies selected from the library were used as candidates. Recombinant plasmids were extracted from these candidates and confirmed using Southern blot analysis (Southern 2006).

The DNA fragment containing tetracycline resistance gene were prepared by digestion of the pBR322 plasmid (Takara Bio Inc., Shiga, Japan) with EcoRI and StyI followed by blunting with T4 DNA polymerase. The resulting fragment was ligated into $\mathrm{CpoI}$ site in the phaCl gene of the KpnI fragment on vector pUC19 after digestion and blunting. The resulting plasmid was digested with KpnI, transformed into A. denitrificans A41 by electroporation (Micro Pulser, BIO-RAD, Hercules, USA), and candidates for the $p h a C 1$ disruptant strain were selected on LB plates containing tetracycline. Colonies were selected from these plates, grown in LB medium containing tetracycline, and chromosomal DNA was extracted as described previously (Sambrook et al. 2001). The phaC1disrupted strains were confirmed and selected using Southern blot analyses.

\section{Bioinformatic analysis of the $\mathrm{A} 41$ genes}

The whole genome sequence of $A$. denitrificans A41 was determined by Takara Bio (Takara Bio Inc., Shiga, Japan). The pha genes and their neighboring sequences in the A41 genome were analyzed using the IMC GE software (available at https://www.insilico-biology.com). Nucleotide and amino acid (aa) sequences were retrieved from the National Center for Biotechnology Information (NCBI) database, and a phylogenetic tree was constructed based on the partial amino acid sequence $(\sim 596$ aa) of PhaC using the maximum-likelihood method. Bootstrap values (1000 replicates) are shown for each branch.

\section{Genome sequence accession number}

Draft genome sequences of Achromobacter denitrificans A41 were deposited into the DNA Data Bank of Japan with accession numbers BLWG01000001-BLWG01001041. 
Table 1 PHA productivity in the one-step cultivation process

\begin{tabular}{lccccc}
\hline C/N ratio & $\begin{array}{l}\text { Cell dry } \\
\text { weight } \\
\text { (mg/L) }\end{array}$ & $\begin{array}{l}\text { PHA } \\
\text { content } \\
\text { (\%) }\end{array}$ & $\begin{array}{l}\text { PHA } \\
\text { composition } \\
\text { (mol \%) }\end{array}$ & \multirow{2}{l}{$\begin{array}{l}\text { PHA yield } \\
\text { (mg/L) }\end{array}$} \\
& & & 3HB & 3HV & \\
\hline 166 & 5.5 & 8.6 & 30.6 & 69.4 & 4.2 \\
83 & 13.2 & 5.9 & 16.5 & 83.5 & 6.4 \\
41 & 31.1 & 4.0 & 6.0 & 94.0 & 10.1 \\
21 & 47.9 & 10.1 & 54.4 & 45.6 & 47.3 \\
2 & 60.9 & 4.3 & 5.2 & 94.8 & 26.4 \\
\hline
\end{tabular}

The cellular content and molar fraction of the $\mathrm{P}(3 \mathrm{HB}-\mathrm{co}-3 \mathrm{HV})$ copolymer were measured using GC

\section{One step $\Longrightarrow$ Two step $\Longrightarrow$ Two step (Ideal case) biphenyl (1) LB (mass) $\quad$ (1) biphenyl (mass) $0.3 \%$ $\begin{array}{ll}\text { (2) biphenyl (polymer) } 0.5 \% & \text { (2) biphenyl (polymer) } 0.3 \%\end{array}$}

Fig. 2 Growth conditions used for PHA production. First, a one-step cultivation method was used with biphenyl as the sole carbon source. Second, as a two-step procedure, initial cultivation was performed for gaining cell mass and the second step was conducted for polymer production. The highest polymer yield was obtained by two-step cultivation using biphenyl as the sole carbon source with controlled cell mass in the PHA production step. mass: culture for gaining cell mass, polymer: culture for PHA production

\section{Results \\ Biosynthesis of $\mathrm{P}$ (3HB-co-3HV) by A. denitrificans A41 from biphenyl as a sole carbon source}

In order to evaluate the possibility of PHA production from biphenyl, we attempted to cultivate strain A41 on biphenyl as a carbon source. We succeeded in biosynthesizing $\mathrm{P}(3 \mathrm{HB}-\mathrm{co}-3 \mathrm{HV})$ from biphenyl using a $\mathrm{C} / \mathrm{N}$ ratio of 21 (Table 1 and Fig. 2). Polymer accumulation was clearly observed using transmission electron microscopy (Fig. 3). This is the first report on the conversion of cytotoxic compound biphenyl to a PHA copolymer with a cellular copolymer content of $10.1 \%$ (Table 1 ).

\section{Improved production of $\mathrm{P}$ (3HB-co-3HV) from biphenyl through a two-step cultivation process}

In order to improve the cellular copolymer content, we used a two-step cultivation method with varying $\mathrm{C} / \mathrm{N}$ ratios. This was performed to attain (a) cell growth for biomass formation, and (b) induction of PHA production under nitrogen limitation conditions by switching from LB rich medium to a poor medium. Expectedly, we obtained an increase in cellular polymer content (26.2\%) when using nitrogen limitation (Table 2 and Fig. 3). The accumulation of polymer was clearly observed using transmission electron microscopy (Fig. 3). Figure 4a shows the time course of biphenyl consumption associated with cell growth by biphenyl assimilation. The biphenyl consumption rates were $0.080 \mathrm{~g} / \mathrm{h}$ (from $12 \mathrm{~h}$ to $48 \mathrm{~h}$ ) and $0.014 \mathrm{~g} / \mathrm{h}$ (from $72 \mathrm{~h}$ to $108 \mathrm{~h}$ ), respectively. However, biphenyl was also used for production of $\mathrm{P}(3 \mathrm{HB}-$ co-3HV). Its consumption rate was $0.087 \mathrm{~g} / \mathrm{h}$ (from $6 \mathrm{~h}$ to $24 \mathrm{~h}$ ) (Fig. 4b). The highest cellular content (47.6\%) of polymer was obtained by two-step cultivation of stain A41 on biphenyl as the sole carbon source (Fig. 5).

\section{Functional analysis of a PHA synthase, PhaC1, encoded in the A. denitrificans A41 genome}

Sequences for two possible PHA synthases were found in different loci of the A. denitrificans A41 genome. Figure $6 \mathrm{a}$ shows the genomic organization of genes related to PHA synthesis. Figure $6 \mathrm{~b}$ shows the phylogenetic relationship among PHA synthases based on the multiple alignment of amino acid sequences. From this phylogenetic tree, PhaC1 can be categorized as a class I PHA synthase, while $\mathrm{PhaC} 2$ remains unclassified. The putative functionality of PhaC1 was evaluated by disrupting the corresponding gene. A negative result for polymer production demonstrated the functionality of PhaC1 (data not shown).

\section{Discussion}

To date, many studies on the utilization of renewable carbon sources have been reported for the production of value-added products such as PHAs (Matsumoto and Taguchi 2013; Kourmentza et al. 2017). The use of xenobiotic compounds as carbon sources for future bioprocesses would be preferable as a solution for environmental problems. The following aromatic compounds have been reported as environmental pollutants: polycyclic aromatic hydrocarbon (Sangkharaket al. 2020) and lignin (Salvachüa et al. 2020). In this study, PCBs/ biphenyl were chosen as promising targets and PHA production was achieved from biphenyl as the sole carbon source using $A$. denitrificans A41, which is capable of degrading PCBs/biphenyl.

In this study, PHA production by strain A41 was first demonstrated under varying $\mathrm{C} / \mathrm{N}$ ratio conditions using a one-step cultivation process. The amount of cell mass obtained through this process was low and PHA production was not expressive. Thus, a two-step cultivation process was used in order to improve PHA productivity. In this case, it was important to address the consumption of biphenyl considering two fermentative events: cell growth and PHA production.

It is well known that the precise quantification of biphenyl is not easy due to the high volatility of this compound. As shown in Fig. 4a, biphenyl was constantly 


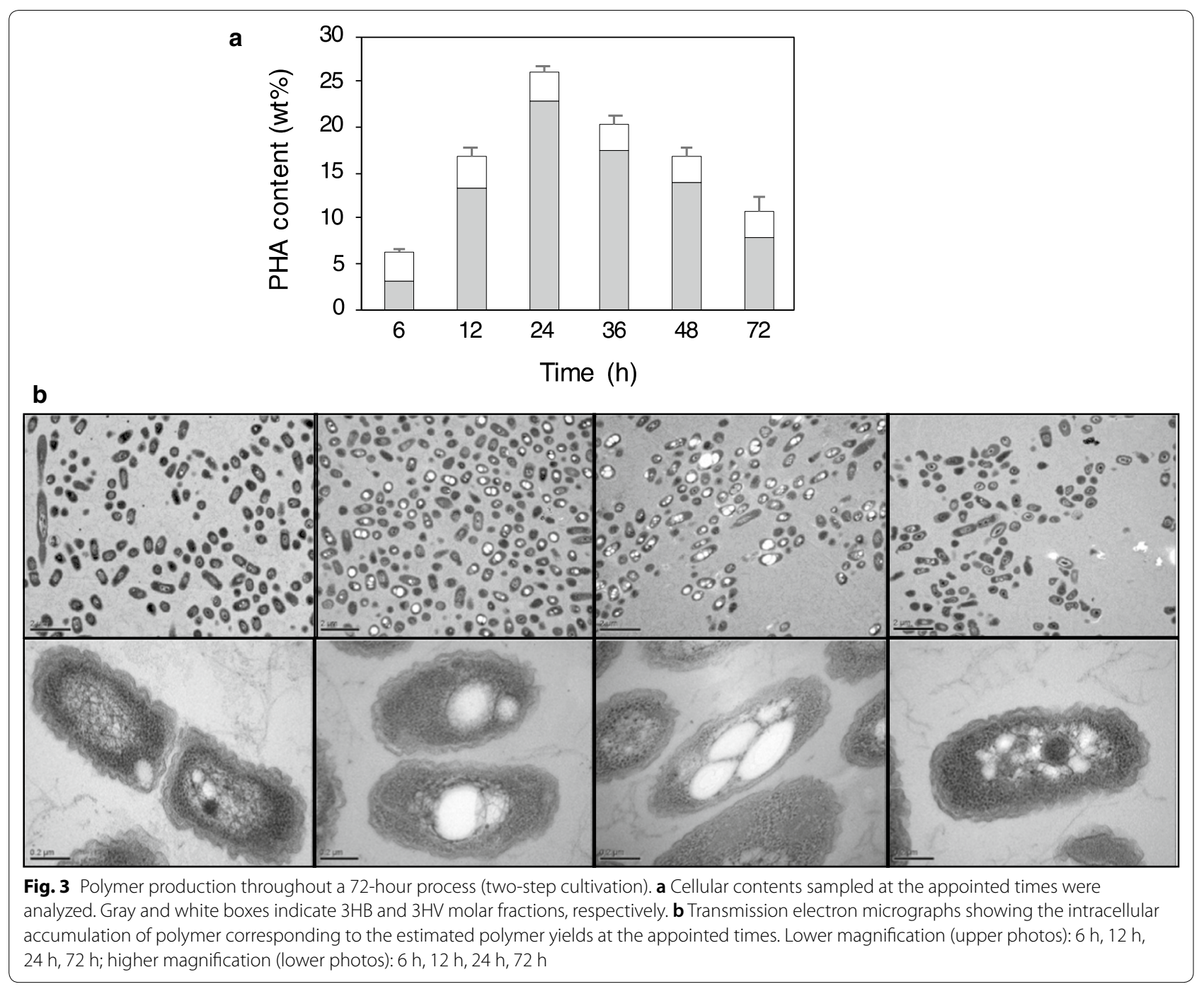

Table 2 PHA production in the two-step cultivation process (24 h)

\begin{tabular}{llllll}
\hline C/N ratio & $\begin{array}{l}\text { Cell dry } \\
\text { weight } \\
\text { (mg/L) }\end{array}$ & $\begin{array}{l}\text { PHA } \\
\text { content } \\
(\%)\end{array}$ & $\begin{array}{l}\text { PHA } \\
\text { composition }\end{array}$ & $\begin{array}{l}\text { PHA yield } \\
\text { (mol \%) }\end{array}$ & \\
\cline { 4 - 5 } & & & 3HB & 3HV & \\
\hline- & 1.15 & 26.2 & 87.0 & 13.0 & 298 \\
166 & 1.21 & 21.3 & 88.5 & 11.5 & 266 \\
21 & 1.71 & 4.1 & 33.6 & 66.4 & 70.0 \\
2 & 1.23 & 3.1 & 12.6 & 87.4 & 38.7 \\
\hline
\end{tabular}

The cellular content and molar fraction of the $\mathrm{P}(3 \mathrm{HB}-\mathrm{co}-3 \mathrm{HV})$ copolymer were measured using GC

consumed for cell growth until $48 \mathrm{~h}$ of culture, which corresponded to the beginning of the stationary phase. The consumption rates remarkably decreased after $72 \mathrm{~h}$.
Approximately $96 \%$ of the added biphenyl was consumed after $108 \mathrm{~h}$. This kinetic transition of biphenyl consumption (from $48 \mathrm{~h}$ to $72 \mathrm{~h}$ ) suggests that cell growth was probably decreased because of the generation of a cytotoxic benzoic acid as an intermediate metabolite.

The next aspect is the feasibility of the use of biphenyl for PHA production. The cellular PHA content was $18.3 \%$ after $12 \mathrm{~h}$ of cultivation under nitrogen limitation conditions (Fig. 4b). Furthermore, the highest cellular content $(47.6 \%)$ was obtained by two-step cultivation with biphenyl as the sole carbon source (Fig. 5). By controlling culture conditions, the conversion from biphenyl to $\mathrm{P}(3 \mathrm{HB}-\mathrm{co}-3 \mathrm{HV})$ was achieved by the strain A41. This successful result may indicate that initial cell growth should first be achieved before PHA production, preferably reducing the cytotoxicity of biphenyl. Regarding the molecular weight of the polymer product, much higher values were obtained than those 

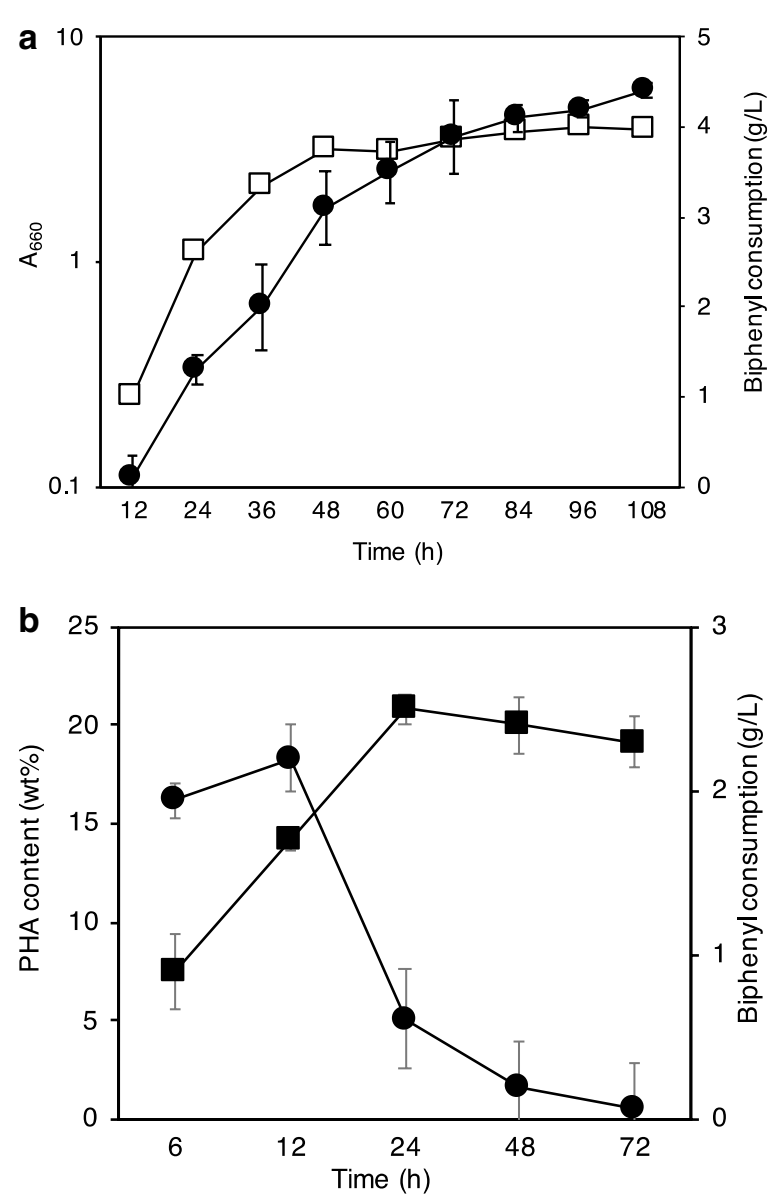

Fig. 4 Biphenyl consumption and polymer production. a Relationship between cell growth and biphenyl consumption. Closed circles indicate biphenyl consumption. Open squares indicate cell growth. Cultivation time range is $120 \mathrm{~h}$. b Relationship between PHA production and biphenyl consumption. Cultivation time range is $80 \mathrm{~h}$. Closed circles indicate biphenyl consumption. Closed squares indicate PHA production. Bars indicate standard deviation in each graph

obtained in the other cases such as the conversion of aromatic hydrocarbon styrene to PHA (Ward et al. 2005; Tan et al. 2015; Arshad et al. 2017). It is of interest to address the reason behind this in our microbial conversion system.

The biosynthesis of copolymer $\mathrm{P}(3 \mathrm{HB}-$ co-3HV) can also be supported by the amino acid sequence deduced from genes encoding PHA synthase PhaC1, which are possibly categorized into the class I PHA synthase family (Fig. 6b). Class I PHA synthases could exhibit substrate specificity toward short-chain-length monomers, $3 \mathrm{HB}$ and $3 \mathrm{HV}$ (Rehm 2003). PhaC1 could at least be involved in polymer biosynthesis, as demonstrated by our gene disruption experiment. The precursor CoA
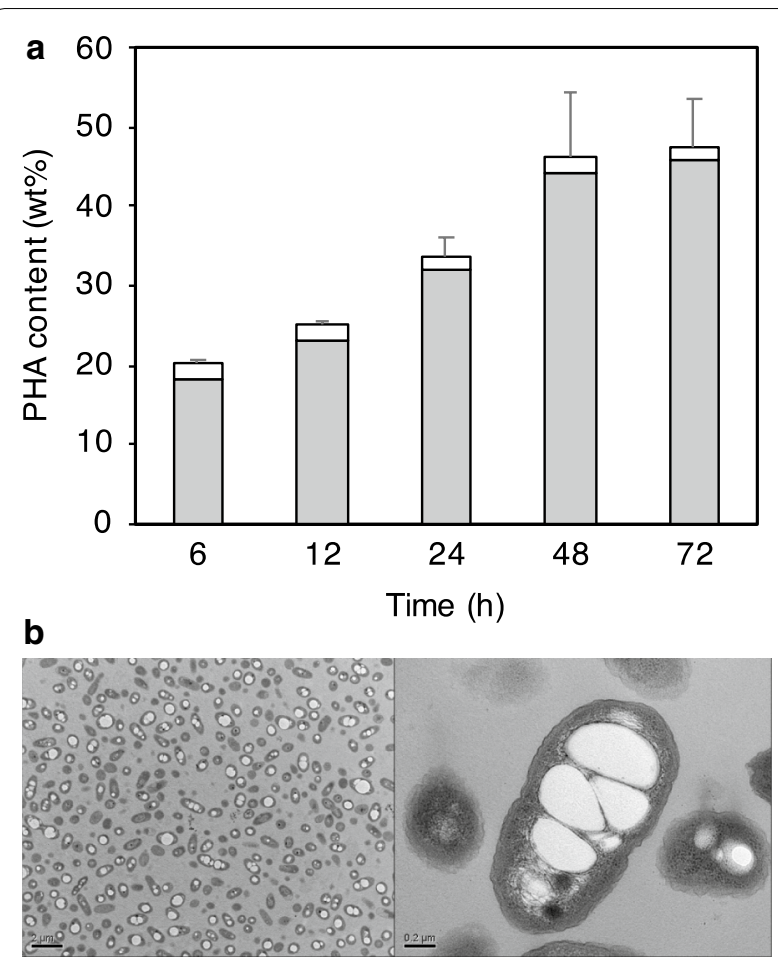

Fig. 5 Time course of polymer production over $72 \mathrm{~h}$ (two-step cultivation process). a Cellular contents sampled at the appointed times were analyzed. Gray and white boxes indicate $3 \mathrm{HB}$ and $3 \mathrm{HV}$ molar fractions, respectively. $\mathbf{b}$ transmission electron micrographs showing the intracellular accumulation of polymer corresponding to the estimated polymer yields at $48 \mathrm{~h}$. lower magnification (left photo); higher magnification (right photo)

forms $3 \mathrm{HB}-\mathrm{CoA}$ and $3 \mathrm{HV}-\mathrm{CoA}$ are generated via two condensation reactions: one with two molecules of acetyl-CoA and the other with one molecule of acetylCoA and one molecule of propionyl-CoA, respectively (Anderson and Dawes 1990). A possible regulator protein (PhaR), encoded downstream to the phaC1 gene, could be a promising target for future PHA biosynthesis strategies.

Considering these findings, we propose a hypothetic pathway for PHA production associated with a previously described biphenyl degradation pathway (Brenner et al. 1994), as illustrated in Fig. 7. Biphenyl is converted to 2-hydroxy-6-oxo-phenylhexa-2,4-dienoic acid (HOPDA) by BphA, BphB, and BphC; benzoic acid and 2-hydroxypenta-2,4-dienoic acid (HPDA) by BphD. Among these compounds, HPDA is metabolized to pyruvate and acetyl-CoA, and this pyruvate is further converted to acetyl-CoA by intracellular enzymes. These acetyl-CoA molecules are used to produce polyhydroxybutyrate (PHB) by $\beta$-ketothiolase (encoded by phaA), NADPH-dependent reductase (encoded by phaB) and PHA synthase (encoded by 
a

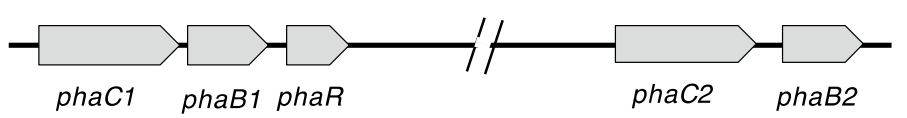

b

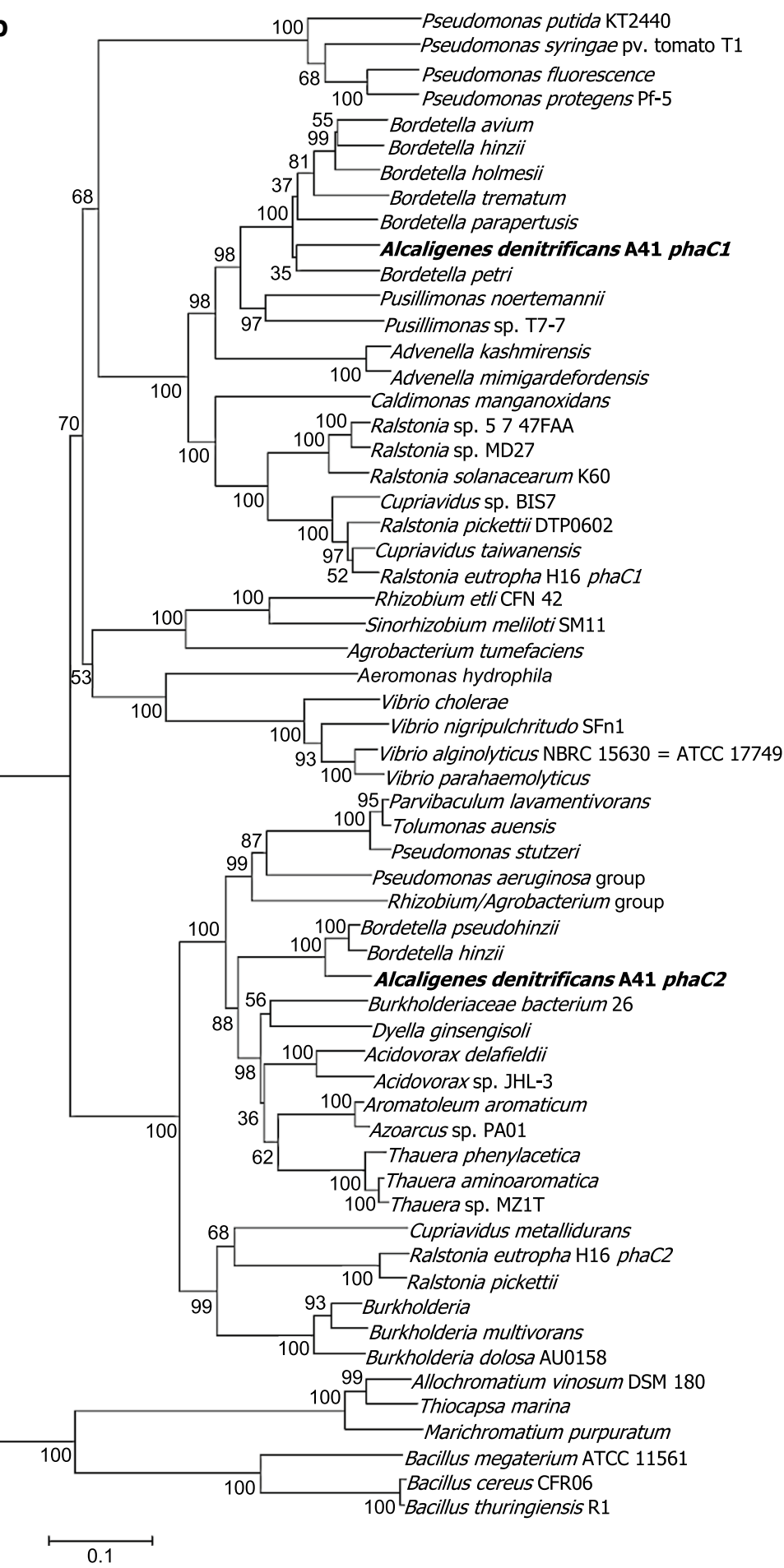

Class II

Class I

Class II

Unclassified

Class III

Class IV 
(See figure on previous page.)

Fig. 6 Organization of PHA synthesis-related genes and phylogenetic tree of PHA synthases. a Gene organization of PHA synthesis-related enzymes in the A. denitrificans A41 genome. Putative PHA synthesis-related genes are termed as phaC1 and phaC2 (encoding PHA synthases), phaB1 and phaB2 (encoding NADPH-dependent reductases), and phaR (encoding a regulatory protein). $\mathbf{b}$ Using Mega 6.0 software, a phylogenetic tree was constructed for classifying a putative PhaC1 of strain A41 based on the amino acid sequences of PHA synthases

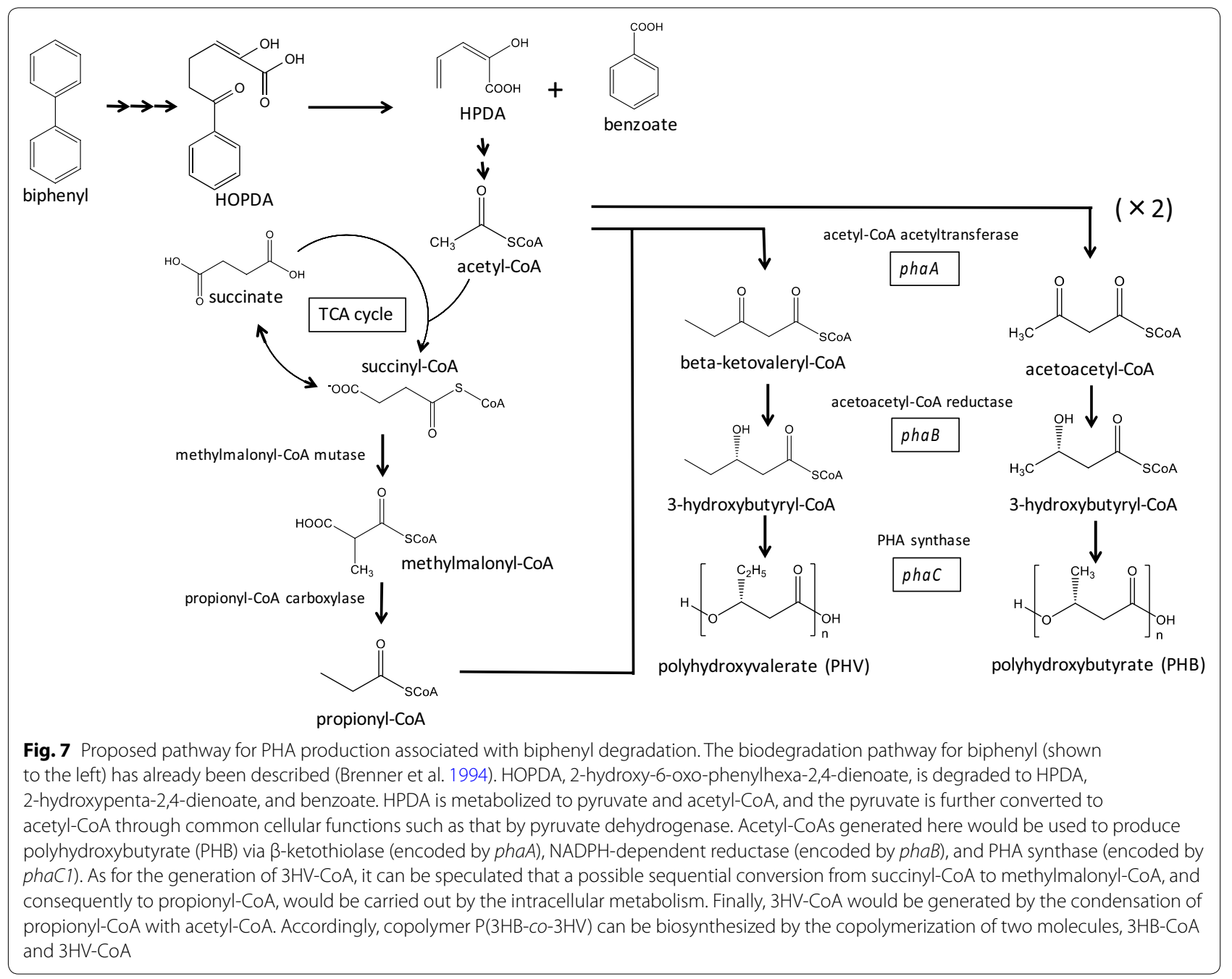

phaC1). Considering the generation of $3 \mathrm{HV}-\mathrm{CoA}$, it can be speculated that a possible sequential conversion from succinyl-CoA to methylmalonyl-CoA, and consequently to propionyl-CoA, would be carried out through intracellular metabolism. Finally, 3HV-CoA would be generated by condensation of propionyl-CoA with acetyl-CoA. Accordingly, copolymer P(3HB-co$3 \mathrm{HV}$ ) could be biosynthesized by the copolymerization of two molecules, 3HB-CoA and 3HV-CoA.

In conclusion, the native strain A41 provided here the prototype of a microbial platform for the production of copolymer $\mathrm{P}(3 \mathrm{HB}-\mathrm{co}-3 \mathrm{HV})$ by supplying a cytotoxic biphenyl. In the near future, a recombinant technology (Zhou et al. 2020) will be applied for the strain A41 platform, in order to improve PHA productivity and alter properties related to molecular weight and monomeric composition.

\section{Acknowledgements}

We would like to thank Dr. J. Sun for polymer analysis and T. Kihara for the cloning of the phaCl locus and Prof. K. Matsumoto for critical reading of this manuscript. Also we would like to thank Editage (www.editage.com) for English language editing. 


\section{Authors' contributions}

MM conceived and designed research. TY, MN and AW conducted experiments and analyzed data. ST contributed analytical experiments and tools. TY, MN, AW and MS prepared the samples for TEM and observed. MS operated TEM. MM and ST wrote the manuscript. All authors read and approved the manuscript.

\section{Funding}

This study was supported by Meiji University.

\section{Availability of data and materials}

All the relevant data used to support the findings of this study are included within the article.

\section{Ethics approval and consent to participate}

Not applicable.

\section{Consent for publication}

Not applicable.

\section{Competing interests}

The authors declare that they have no conflict of interest.

\section{Author details}

${ }^{1}$ Microbial Genetics Laboratory, Department of Agricultural Chemistry, School of Agriculture, Meiji University, 1-1-1 Higashimita, Tama-ku, Kawsaki, Kanagawa 214-8571, Japan. ${ }^{2}$ Department of Chemistry for Life Sciences and Agriculture, Faculty of Life Sciences, Tokyo University of Agriculture, 1-1-1 Sakuragaoka, Setagaya, Tokyo 156-8502, Japan.

Received: 23 June 2020 Accepted: 17 Auqust 2020

Published online: 26 August 2020

\section{References}

Anderson AJ, Dawea EA (1990) Occurrence, metabolism, metabolic role, and industrial uses of bacterial polyhydroxyalkanoates. Microbiol Rev 54:450-472

Arshad A, Ashraf B, Ali I, Jamil N (2017) Biosynthesis of polyhydroxyalkanoates from styrene by Enterobacter spp. isolated from polluted environment. Front Biol 12:210-218

Braunegg G, Sonnleitner B, Lafferty RM (1978) A rapid gas chromatographic method for the determination of poly- $\beta$-hydroxybutyric acid in microbial biomass. Eur J Appl Microbiol Biotechnol 6:29-37

Brenner V, Arensdorf JJ, Focht FF (1994) Genetic construction of PCB degraders. Biodegradation 5:359-377

Collard JM, Corbisier P, Diels L, Dong Q, Jeanthon C, Mergeay M, Taghavi S, van der Lelie D, Wilmotte A, Wuertz S (1994) Plasmids for heavy metal resistance in Alcaligenes eutrophus CH34: mechanisms and applications. FEMS Microbiol Rev 14:405-414

Grunstein M, Wallis J (1979) Colony hybridization. Methods Enzymol 68:379-389

Hinteregger C, Streichsbier F (2001) Isolation and characterization of Achromobacter xylosoxidans T7 capable of degrading toluidine isomers. J Basic Microbiol 41:159-170

Hughes EJL, Bayly RC (1983) Control of catechol meta-cleavage pathway in Alcaligenes eutrophus. J Bacteriol 154:1363-1370

Kourmentza C, Plácido J, Venetsaneas N, Burniol-Figols A, Varrone C, Gavala HN, Reis MAM (2017) Recent advances and challenges towards sustainable polyhydroxyalkanoate (PHA) production. Bioeng 4:55-97
Maeda M, Ohta Y, Kang S-K, Lee L, Kudo T (1997) The evolution of meta-cleavage pathway for degradation of polychlorinated biphenyl (PCB)/bipheny in Gram-negative bacteria. In: Horikoshi K, Fukuda M, Kudo T (eds) Microbial diversity and genetics of biodegradation. Karger, Basel, pp 149-168

Maeda M, Roberts MS, Ohta Y, Fuji F, Travisano M, Kudo T (1998) Isolation and characterization of a new alkaliphilic bacteria. J Gen Appl Microbiol 44:101-106

Matsumoto K, Taguchi S (2013) Enzyme and metabolic engineering for the production of novel polymers: crossover of biological and chemical processes. Curr Opin Biotechnol 24:1054-1060

Ohta Y, Maeda M, Kudo T, Horikoshi K (1996) Isolation and characterization of solvent-torelant bacteria which can degrade biphenyl/polychlorinated biphenyls. J Gen Appl Microbiol 42:349-354

Raberg M, Volodina E, Lin K, Steinbüchel A (2018) Ralstonia eutropha H16 in progress: applications beside PHAs and establishment as production platform by advanced genetic tools. Crit Rev Biotechnol 38:494-510

Rehm BH (2003) Polyester synthases: natural catalysis for plastics. Biochem J 376(pt 1):15-33

Salvachúa D, Rydzak T, Auwae R, De Capite A, Black BA, Bouvier JT, Cleveland NS, Elmore JR, Huenemann JD, Katahira R, Michener WE, Peterson DJ, Rohrer H, Vardon DR, Beckham GT, Guss AM (2020) Metabolic engineering of Pseudomonas putida for increased polyhydroxyalkanoate production from lignin. Microb Biotechnol 13:290-298

Sambrook J (2001) Molecular cloning: a laboratory manual. Cold Spring Harbor, N.Y.:Cold Spring Harbor Laboratory Press

Sangkharak K, Choonut A, Rakkan T, Prasertsan P (2020) The degradation of phenathrene, pyrene, and fluoranthene and its conversion into mediumchain-length polyhydroxyalkanoate by novel polycyclic aromatic hydrocarbon-degrading bacteria. Curr Microbiol. https://doi.org/10.1007/ s00284-020-01883-x

Schlegel HG, Gottschalk G, von Bartha R (1961) Formation and utilization of poly-beta-hydroxynutyric acid by Knallgas bacteria (Hydrogenomonas). Nature 191:463-465

Southern E (2006) Southern blotting. Nat Protoc 1:518-525

Springael D, Krebs S, Mergeay M (1993) Identification of catabolic transposon, Tn4371, carrying biphenyl and 4-chlorobiphenyl degradation genes in Alcaligenes eutrophus A5. J Bacteriol 175:1674-1678

Springael D, Diels L, Mergeay M (1994) Transfer and expression of PCB-degradative genes into heavy metal resistant Alcaligenes eutrophus strains. Biodegradation 5:343-357

Tan G-YA, Chen C-L, Ge L, Li L, Tan SN, Wang J-Y (2015) Bioconversion of Styrene to Poly(hydroxyalkanoate) (PHA) by the New Bacterial Strain Pseudomonas putida NBUS12. Microbes Environ 30:76-85

Tomizawa S, Imamura T, Maeda M (2015) Identification and conjugative transfer of the $\mathrm{ICE}_{\text {Adl }}$ element in a PCB-degrading bacterium Alcaligenes denitrificans A41 (unpublished). Direct submission. GenBank: AB471892

Ward PG, de Roo G, O'Connor KE (2005) Accumulation of polyhydroxyalkanoate from styrene and phenylacetic Acid by Pseudomonas putida CA-3. Appl Environ Microbiol 71:2046-2052

Zhou Y, Lin L (2020) Development of a CRISPR/Cas9n-based tool for metabolic engineering of Pseudomonas putida for ferulic acid-to-polyhydroxyalkanoate bioconversion. Commun Biol 3:98. https://doi.org/10.1038/s4200 3-020-0824-5

\section{Publisher's Note}

Springer Nature remains neutral with regard to jurisdictional claims in published maps and institutional affiliations. 